\title{
Analysis of The Use of Low-Cost Strategy for SMEs in Indonesia in Covid Pandemic-19
}

\author{
Aprilia Ningrum Ambarwati, Setyo Riyanto \\ Economics and Business Faculty Student, Mercu Buana University, Jakarta, Indonesia \\ Associate Professor, Mercu Buana University, Jakarta, Indonesia \\ Email: ningruma531@gmail.com
}

\section{ARTICLE INFO}

Date received : 28 June 2020

Revision date : 01 September 2020

Date received : 09 september 2020

Keywords:

Industrial Revolution

Educational Reformulation

School Religiosity

\begin{abstract}
The Coronavirus that was present in the midst ofa society in 2020 really caught the attention. The visible impact not only affects public health but also affects the economy and MSMEs not only in Indonesia but also in various countries. Because of its spread that is too fast then in a number of countries to close the area, which resulted in the difficulty of export and import goods, therefore MSMEs who were previously able to get goods from out of town finally only got goods in Indonesia. This topic will discuss the use of lowcost strategies in MSMEs, especially in Indonesia. The research method used is a descriptive research and based on the results of the questionnaire. And the results of this study indicate that during this pandemic period, consumers are looking for relatively low prices. This is evidenced by the use of the low-cost strategy at MSMEs in this pandemic era.
\end{abstract}

\section{INTRODUCTION}

The company's strategy in achieving competitive advantage must differ from one company to another. 3 generic strategies can be carried out by companies as an effort to increase business in increasingly fierce business competition to achieve and maintain a competitive advantage. Michael R. Porter in Ritika Tanwar (2013) mentions 3 strategies, namely the Differentiation Strategy (Differentiation).

Cost Leadership and Cost Focus. Cost Leadership is a corporate strategy by minimizing costs so that the costs incurred when using this strategy will be lower compared to companies that use the Differentiation or Focus strategy.

The Cost Leadership Strategy can make companies gain greater profits because companies can reduce production costs so that prices can compete and company profits can increase. Thus the company's performance for the better. Hashem Valipour, Hamid Birjandi, and Samira Honarbakhsh (2012) explained that the company with the implementation of Cost Leadership Strategy shows that financial leverage, business strategy, and dividends payout will positively influence company performance.

Improved company performance that implements a Cost Leadership Strategy can be achieved with strict cost control. Companies must make efforts to minimize costs in all aspects of the business. In this case, the company emphasizes more on efficiency, where the company produces high volumes, and the products produced are standard products.

Some companies that have implemented this strategy are Charles Schwab in discount brokers, Wal-Mart in discount retailers, Texas Instruments in consumer electronics, Emerson Electric in electric motors, Hyundai in automotive, Dell in computers, Black and Decker in machine tools, Nucor in steel, Lincoln Electric in welding equipment and $\mathrm{BIC}$ in pens. In Indonesia, some companies also implement a Cost Leadership strategy, such as PT. Citilink Indonesia, a subsidiary of PT Garuda Indonesia in the Airlines. 
In this study, the analysis was conducted at Mata Air MSMEs, which produce Muslim men's clothing, such as pants and sirwal clothes. These clothes appear for Rp 150,000 / pcs for clothes and Rp. 110,000 / pcs for pants. The price is lower than the products already on the market with the same brand.

UMKM Mata Air is a home industry business that produces Muslim clothing. Mata Air's MSME owner, Yan FendriMasri said that this business is part of a family business from Padang, West Sumatra, which is a clothing business that was established in 2015 and already had a Mata Air brand certificate in 2016. Since its first launch in 2015, clothing sales are quite high. From 2015 to 2020, the company's business continues to grow.

The development of UMKM Mata has been proven for five years of operation in Tangerang, Mata Air has had two convections. The First Convection is on Jl. Garuda Blok A-31 Kunciran Indah, Tangerang, and the Second Convection are on J. H. Asep, Tangerang.

In the production process, the Mata Air clothing empowers local entrepreneurs by using the largest raw material, namely sugar from Indonesia. The difference between Air Mata UMKM and other Muslim clothing business is the target market. Mata Air MSMEs determine the target of middle and upper-middle-class consumers. This effort makes an effort to fit a predetermined target market, which reduces costs so that the price is lower when compared to other brands of Muslim clothing with similar material quality.

The implementation of the Cost Leadership Strategy can improve company performance as implemented by Air Mata UMKM, but some weaknesses are vulnerable to several risks such as the emergence of new competitors with imitation products that have lower prices, the attitude of lack of attention to the needs and customer satisfaction because of concerns excessive to minimize costs. Based on the description above, it can be seen that the implementation of a Cost Leadership strategy that can improve business performance has several risks or weaknesses that can make a business unable to maintain excellence in competitive competition. This is what drives researchers to research the Cost Leadership Strategy implemented by Mata Air's SMEs in Tangerang and how efforts MSMEs can do in minimizing risk so that businesses can maintain a competitive advantage. Thus the researcher wants to raise the title "ANALYSIS OF THE USE OF LOW-COST STRATEGY FOR SMES IN INDONESIA IN COVID19".

In current pandemic situations, where human space has begun to reduce the risk of transmission of a Covid-19 (Ratih Komala Sari, 2020) turns out Covid-19 it has given the impact on the sales system that is decreasing the buy and sell the system in MSMEs and declining the Indonesian budget that requires the community to be intelligent in managing finances during a pandemic like this. Because the impact of this pandemic is very influential on the Indonesian economy and affects the Indonesian buying and selling system, thus, competition in the industry will increase rapidly due to these factors. Many small and large sectors of the industry are still operating during the current pandemic, of course, this is not an easy thing to do during this pandemic because sellers are asked to innovate and keep up with the trend so that sales remain standing and do not experience a turnover, and sellers must smart in fighting for customer satisfaction. The first impact is felt at the company's HR because at this pandemic (Setyo Riyanto, 2017)because in this pandemic the company began to reduce employees by doing layoffs in order to pay their salary and because of the order from the Government that requires doing social distancing so as to prevent the growth of the plague. In addition sales sector also affected, namely in micro, small and medium enterprises (SMEs), which is one of the sub sectors that should be concerned about the central role in maintaining investment in Indonesia. About $90 \%$ of the workforce is absorbed in this sector and its contribution to GDP is $60 \%$.

aCases of COVID 19 infected in Indonesia began on March 2, 20. At that time president Joko Widodo announced two positively infected citizens of the Coronavirus, a 31-year-old woman and a 61year-old mother (detik.com, 2020). It did not take long since the announcement that people infected with the Coronavirus spread to almost provinces throughout Indonesia. The first impact of the presence of the Coronavirus in Indonesia is the decline in the buying and selling system at MSMEs and the decrease in the Indonesian budget which requires Indonesians to be smart in managing finances, especially during a pandemic like this. And many industrial sectors still operate during the current pandemic. Of course, it is not an easy thing to rise against this threat influenced by COVID-19. not only affects MSME but also affects companies that not only require fighting for employee satisfaction and then bring up employees but must also increase customer satisfaction because the influence of this pandemic will be endowed by the state which further increases the number of companies which increases the number of employees that can be accepted as requested by employees. Thus, Indonesia can compete in industries that make competition increase even in a pandemic like this.

The Corona outbreak did not only hit finance in Indonesia but also hit various state finances. Therefore the most effective way to deal with the spread of the virus is to conduct social distancing and locking actions although it will have an impact on slowing economic activity (supply and 
demand). Therefore the risk of disruption in the economic sector that can occur at any time must be realized by the government by providing sub-sectors that discuss policy changes in making appropriate policies about the virus.

The impact that was first seen in the sales sector, namely on micro, small and medium enterprises (MSMEs), is one of the sub-sectors that must receive attention related to the central role in maintaining investment in Indonesia. About $90 \%$ of the workforce is absorbed in this sector, and its contribution to GDP is $60 \%$. The LIPI Economic Research Center (P2E) made calculations that discussed coronaviruses to remove MSMEs to be stored here, as well as the wood and rattan handicraft business.

\section{LITERATURE REVIEW}

Small and medium enterprises (SMEs)

UMKM is a trading business that is managed by a business entity or an individual that refers to a productive economic business by the criteria established by Law Number 20 the Year 2008.

The understanding of SMEs and Small Industries, according to various experts, is as follows:

a. According to the Industry and Trade Office (Disperindag).

Small Industry is a trade industry that has a workforce of between 5-19 people.

b. According to the Central Statistics Agency (BPS). Small Industry is a company with a workforce of fewer than 20 people, including paid workers, owner workers, and unpaid family workers.

c. According to the Ministry of Finance.

Small businesses are family-owned or individualowned production businesses of Indonesian citizens who have sales assets of at most $\mathrm{Rp} 1$ billion / year.

d. According to the State Minister for Cooperatives and SMEs.

Small Business is owned by Indonesian citizens both individuals and legal entities that have a net worth of as much as Rp 200,000,000 and has a turnover or output value of 15 sales at most $\mathrm{Rp}$ $1,000,000,000$ and the business stands alone

\section{Low-Cost Strategy}

Cost leadership, commonly referred to as Low Cost is one of the strategies that can be applied by companies as a form of help needed in competitive competition. The way to compete in this strategy is to replace the lowest possible cost compared to competitors.

Low-cost strategies that can be achieved through several meetings, namely:

1. Economic scale in production

2. The impact of the learning curve
3. Strict cost control

4. Cost minimization

\begin{tabular}{|l|c|}
\hline \multicolumn{1}{|c|}{ Cost Management } & \multicolumn{1}{|c|}{$\begin{array}{c}\text { Strategic } \\
\text { Pressure } \\
\text { Low Cost }\end{array}$} \\
\hline $\begin{array}{l}\text { The role of production costs and } \\
\text { techniques in assessing } \\
\text { performance }\end{array}$ & \begin{tabular}{l} 
Very important \\
\hline $\begin{array}{l}\text { The importance of flexible } \\
\text { budgeting for } \\
\text { controlling production costs }\end{array}$
\end{tabular} \\
\hline $\begin{array}{l}\text { Perception of the importance of } \\
\text { budget meetings }\end{array}$ & $\begin{array}{c}\text { High to very } \\
\text { High }\end{array}$ \\
\hline
\end{tabular}

One step in accomplishing Taken a toll Administration is to approach economies of scale in a generation. Agreeing to Pearson and Wisner (1993), economies of scale can be partitioned into two to be specific volume economies of scale and learning economies of scale. The volume of economies of scale may be a diminish in unit costs gotten from an increment in generation capacity. Learning economies of scale concerns the diminishment in unit costs gotten from the change experienced by the company such as expanding the capacity of workers, the generation preparation, and arranging that collects over time. This learning economies of scale are related to the learning bend concept which states that there's a diminishing in unit costs on the off chance that a handle is rehashed.

Taken a toll control and endeavors to play down costs in all viewpoints to require consideration. In this case, the concept of key taken a toll administration states that distinctive methodologies require diverse taken toll viewpoints or diverse methodologies require diverse taken a toll administration and control frameworks.

The following table presents cost management pressures where the strategy is chosen is a low-cost strategy.

Table 2.1

Cost Management with a Low-Cost Strategy

\begin{tabular}{|l|c|}
\hline $\begin{array}{l}\text { The importance of marketing } \\
\text { cost analysis }\end{array}$ & $\begin{array}{c}\text { Often not done } \\
\text { in a manner } \\
\text { formal }\end{array}$ \\
\hline $\begin{array}{l}\text { The importance of production } \\
\text { costs as input indetermining the } \\
\text { selling price }\end{array}$ & High \\
\hline $\begin{array}{l}\text { The importance of competitor } \\
\text { cost analysis }\end{array}$ & High \\
\hline
\end{tabular}

Sumber: Supriyono (1999)

Based on the table above, it can be concluded that the control and supervision of production costs arevery important. This is a strategic step that must be taken to reduce costs as low as possible and analyze the costs of 
competitors to achieve Cost Leadership or cost leadership to achieve competitive advantage.

Porter (1980) contends that the Cost Leadership Strategy is an exertion by companies to deliver competitive points of interest by accomplishing the least costs within the industry. The center of companies that execute the Fetched Authority methodology is tight fetched control, abstaining from all exercises that bring about expansive costs and prioritizing proficiency in each operation.

Companies in Indonesia are more cautious in deciding the offering cost of the items delivered. In this case, the company will take into consideration people's obtaining control with the trust of expanding deals volume. The Fetched Authority Technique concurring to Aulakh (2000) in Baroto et al, (2012) is the favored corporate procedure in creating nations such as Indonesia, Malaysia, India, and China. This is often since these nations have lower labor costs so that generation costs are lower. Moo generation costs, the company can offer items at lower costs among competitors. In this way, the objective of the Fetched Authority methodology can be accomplished.

\section{METODE}

This type of research conducted at this writing is to use a descriptive research model, and based on the results of a questionnaire distributed to clothing business employees (Mata Air), amounting to 20 people obtained the results of 10 respondents male sex. Namely how to respond to the use of lowcost strategies during this pandemic. Respondents are familiar with information about the clothing business (Mata Air). This determination is based on the usefulness of the research conducted; descriptive research is research conducted to determine the value of a variable or more without making comparisons or connecting with other variables. At the same time, the literature review method is one of the data collection methods used in the social research methodology to track data. Data are also obtained from certain documents that can provide additional information in this article relating to the analysis of the use of a low-cost strategy for Indonesia in Indonesia on CoPandemic-19.

\section{RESULTS AND DISCUSSION}

At a see, roughly the utilize of low-cost systems in bargains inside the current broad, in this consider demonstrating of announcement communicating the seller's experience in dealing with this far-reaching by utilizing a low-cost framework. Specifically in SMEs bolted in in this clothing which needs utilizing this moo brought procedure since of the requirements of clients due to the current broad, by doing this strategy it is expected that dress (pants) will offer without a doubt in case they do not take advantage as some time recently being hit by this broad in organizing to outlast and to be able to actuate back the capital in fact in show disdain toward of the truth that it does not get an advantage as usual.

Based on official government information dated May 7, 2020, the number of affirmed cases of co-19 in Indonesia is 12,438 cases. With this inquire and control, the community is anticipated not to require of the house; of course, this may affect different things checking MSMEs. Through the official area of the good thing about cooperatives and MSME states, the spread of co-19 has the potential to impact the economy counting the common sense of cooperatives, miniaturized scale, little and medium businesses. Based on acknowledgments, the conventional MSME felt a reduction in turnover within the middle of the COVID-19. This happens since of the decreased improvement exterior the family, along with these lines commerce visionaries, have a burden in getting harsh materials due to transportation obstructions, as well as a, reduce in open certainty in things that are exterior, particularly interior the culinary field. UMKM, which is one of the money related supporters since it was other than gives a parcel of jobs, with this co-19, as well started to lay off or lay off fleeting operators since the company/commerce they need to be a nearby chance. Other disclosures based on Acknowledgment, not all MSMEs felt a decrease in deals turnover and had to close their businesses, some MSMEs were still reliable and experienced an increase in deals turnover since they made changes in terms of things and executed a few showing strategies to outlive. There are a few things that can be done by MSMEs to outlive the current pandemic, specifically by employing a low-cost procedure. In expansion to utilizing the moo fetched procedure, MSME proprietors too have some things that MSMEs can do as follows:

\section{E-Commerce}

Interior, the center of this 19th, encourage deals for the preeminent parcel experienced a lessen due to the arrangement of more individuals remaining at private. In improvement, different MSMEs select not to open their shops or businesses due to detainments on working hours or the bother of Immense Scale Social Restrictions (PSBB) in numerous areas. One way to keep running commerce and reach more clients and grow to advertise share is to require advantage of $e$ commerce deals. E-commerce can be a arrange of buying and publicizing things electronically by buyers and from company to company with computers as center individuals for trade 
exchanges. E-commerce which was at, to begin with a web retail deals component, by and by highlights a broader meaning. related to little businesses, e-commerce consolidates a positive but not essential influence in progressing execution. In this case, businesses are prompted to be able to exchange in e-commerce but there must be offer help for the government or specialists and instruction to be able to supply heading to commerce on-screen characters so that they have palatable information and can in a culminate world utilize this e-commerce. Interior the time of mechanical change, on-screen commerce characters ought to without an address have moved to e-commerce trading since the arrange of trade and buyer contributing has begun to move, besides the closeness of the COVID-19 distant coming to that produces e-commerce exchanging an uncommon choice for on-screen characters MSMEs to outlive in reality have the potential to be able to reach display day show share.

\section{Customer Relationship Marketing (CRM)}

In this Evacuated coming to period, SMEs need to be not since it was center on capturing cutting edge clients but must keep up things and keep up existing clients, making client fulfillment and making client consistency. Persevering clients will not move to another since they, as of particularly, have recognized in our things. One way for MSMEs to be able to outlive internal parts the center of declining trade growing is to do client relationship progressing. Client relationship progressing may be a progressing procedure concept that looks to set up long-term affiliations with clients, especially keeping up solid and commonly basic affiliations between advantage suppliers and clients that can make go over exchanges and make client steadiness. Trade performing experts can appear up concern that in expansion centers to show things. Cases of how to create client relationships showing by developing affectability for this flare-up such as giving promos or free thing plans for dispatches carrying out advantage development, setting aside a designate of the pay from publicizing things to individuals requiring. This way can as well create client certainty and client holding. So within the middle of this far-reaching, we SMEs don't since it thought around themselves, but create client progressing affiliations by appearing up concern and positive things done by commerce performing pros. In expansion, MSME performing masters can build up communication with clients completely diverse media movements and e-commerce that are had crave, such as replying deals complaints or replying exceptional reactions from clients, this furthermore makes positive client engagement.

\section{CONCLUSION}

In conclusion, the use of a low-cost strategy in sales at the pandemic COVID-19 is very helpful for sellers' economies who were previously confused in selling their products, due to the declining Indonesian economy due to the cessation of the buying and selling system not only in Indonesia but in various countries. The sellers are required to lock down to prevent the spread of COVID-19. That way the seller is asked to be smarter in using existing strategies to stay afloat at this time.

\section{REFERENCES}

Taufik, T., \& Ayuningtyas, E. A. (2020). Dampak Pandemi Covid 19 Terhadap Bisnis Dan Eksistensi Platform Online. Jurnal Pengembangan Wiraswasta, 22(01), 21-32.

Indonesia Polarization, Democratic Distress, and the Coronavirus - Polarization and the Pandemic - Carnegie Endowment for International Peace. (n.d.).

(PDF) Emotional Intelligence and Anxiety at Workplace_ Study on Operation Warehouse Employee $\mathrm{YCH}$ Indonesia in Pandemic Situation COVID-19_ Ratih Komala and Setyo Riyanto - Academia. (n.d.).

Akob Kadir, H. (2015). The role of small and medium enterprises (UKM) with Human Resources (HR) Based in Face of MEA 2015 in Indonesia. International Journal of Advanced Research, 3(4), 399-410.

Riyanto, S. (n.d.). Lukertina.(2019). Does the Good Corporate Governance Culture Good for Workers. IOSR Journal of Business and Management.

Regulasi / Gugus Tugas Percepatan Penanganan COVID-19.

https://covid19.go.id/p/regulasi

(n.d.).

ILO, I. L. O. (2016). Workplace Stress: A Collective Challenge. Labour Administration, Labour Inspection and Occupational Safety and Health 
Dressen, M., \& Durand, J.-P. (2018).

Introduction to Low Cost theory.

Producing low cost. La Nouvelle Revue Du Travail, 12.

Simbolon, R., \& Riyanto, S. (2020). How Retail Survive Against Pandemic of COVID-19: An Insight from Optical Retailer. International Journal of Current Science and Multidisciplinary Research, no-124.

Riyanto, S., Sutrisno, A., \& Ali, H. (2017). The Impact of Working Motivation and Working Environment on Employees Performance in Indonesia Stock Exchange. International Review of Management and Marketing, 7(3).

Pattnaik, R., Pradhan, R. K., \& Jena, L. K. (2016). Emotional intelligence and anxiety at workplace: Study on security personnel employed in educational institution. Indian Journal of Positive Psychology, 7(2), 172.
Suharsimi, A. (2006). Prosedur penelitian suatu pendekatan praktik. Jakarta: Rineka Cipta.

Valipour, H., Birjandi, H., \& Honarbakhsh, S. (2012). The effects of cost leadership strategy and product differentiation strategy on the performance of firms. Journal of Asian Business Strategy, 2(1), 14

Tanwar, R. (2013). Porter's generic competitive strategies. Journal of Business and Management, 15(1), 11-17.

Baroto, M. B., Abdullah, M. M. Bin, \& Wan, H. L. (2012). Hybrid strategy: A new strategy for competitive advantage. International Journal of Business and Management, 7(20), 120.

\section{Copyright holder :}

Aprilia Ningrum Ambarwati, Setyo Riyanto (2020)

First publication right :

Journal of Social Science

This article is licensed under:

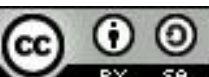

